Wzniostośc i makabra w literackich obrazach śmierci, red. Michał Kuran, Łódź 2014, „Analecta Literackie i Językowe", t. IV.

BeAta ProkopczyK ${ }^{1}$

Uniwersytet Łódzki

\title{
„JAĆ TYLKO W JEDNEJ ULUBIONEJ ŻYŁEM. UMAREA! WSZYSTKO STRACIEEM” — o MIŁośCI I ŚMIERCI W ŻALACH ORFEUSZA NAD EURYDYKA FrancisZka Dionizego Kniaźnina
}

Żale Orfeusza nad Eurydyką są pierwszym w całości oryginalnym zbiorem Kniaźnina, ponadto jest to pierwsza praca, z której poeta był dumny i w pełni zadowolony ${ }^{2}$. Utwory te zostały napisane już w 1780 lub 1781 roku, jednak opublikowano je dopiero w 1783 roku w Wierszach. Z pewnością miały one duże znaczenie dla Kniaźnina, skoro $\mathrm{w}$ nieco zmienionej wersji zamieścił je także w zbiorze wydanym w latach 1787-1788 oraz w rękopisie z lat 90., stanowiącym niejako jego testament poetycki. W swoich rozważaniach będę korzystała z ostatniego przekazu Żalów Orfeusza nad Eurydyką (zamieszczonego we wspomnianym autografie), na który składają się 23 utwory poprzedzone wierszem dedykacyjnym.

Powstanie Żalów wiąże się z tragedią rodzinną Franciszka Zabłockiego, serdecznego przyjaciela poety. Co prawda, w biografii Zabłockiego jest wiele luk, jednak wiadomo, że około roku $1776^{3}$ ożenił się z aktorką sceny warszawskiej, nieznaną z nazwiska Katarzyna, o której nie ma zbyt wielu informacji. Musiało to być silne uczucie, skoro Franciszek z Wołynia zdecydował się na małżeństwo. Jak pisze Stanisław Paluchowski:

Były to przecież czasy, w których aktorów uważano za coś bardzo niskiego, a ich zawód za zajęcie, przynoszące ujmę człowiekowi; zachodziły nawet wypadki odmawiania aktorom chrześcijańskiego pogrzebu! ${ }^{4}$

\footnotetext{
${ }^{1}$ Beata Prokopczyk — doktorantka w Katedrze Edytorstwa Uniwersytetu Łódzkiego, sekretarz Koła Naukowego Edytorów UŁ, redaktor, korektor, autorka artykułów dotyczących twórczości Franciszka Dionizego Kniaźnina oraz Franciszka Zabłockiego (m.in. Relacja między poetą a tekstem - o wierszach funeralnych Franciszka Dionizego Kniaźnina zawartych w zbiorze "Erotyki” oraz Komedie Franciszka Zabtockiego jako przykład szerzenia myśli oświeceniowej, podejmowania polemiki z sarmatyzmem oraz ksztaltowania nowego wzorca osobowego wśród Polaków). Jej zainteresowania badawcze koncentrują się wokół edytorstwa naukowego oraz zagadnień związanych z analizą i interpretacją dzieł literackich końca XVIII wieku.

2 A. J. Czartoryski, Życie Kniaźnina (z manuskryptu pisanego w r. 1817), „Przegląd Poznański” 1853 , t. 16 , s. 121 .

${ }^{3}$ Taką datę podaje Janina Pawłowiczowa; zob. Kalendarium życia i twórczości, [w:] Teatr Franciszka Zabłockiego, t. 5, oprac. J. Pawłowiczowa, Wrocław 1996, s. 344.

${ }^{4}$ S. Paluchowski, Kniaźnin i Zabłocki w stosunku do siebie i dworu Czartoryskich, „Sprawozdanie Dyrekcji

C. K. Gimnazjum V we Lwowie za rok szkolny 1907”, Lwów 1907, s. 16.
} 
Młody pisarz niedługo cieszył się pożyciem małżeńskim — Kasia zmarła, prawdopodobnie po połogu, wraz z dzieckiem. Nie ma jednak pewnych informacji na temat potomstwa Zabłockiego. Dawny przyjaciel poety, niejaki Grümberg, który mieszkał z nim po tej tragedii, w liście do Jana Richtera pisze następująco o tych wydarzeniach:

[Zabłocki - przyp. B.P.] Przebywając w Warszawie, miał zręczność dania się poznać ze swoim talentem i gustem do sztuk teatralnych. To było powodem wejścia w ściślejsze zażyłości z aktorami i aktorkami, z których rzędu pojął żonę (nie pamiętam jej familii), z nią spłodził dziecię (podobno córeczkę), lecz tę, jako i żonę, niedługo po połogu utracił5.

Z kolei w artykule Franciszek Zabłocki ( $z$ drzeworytem), który ukazał się w „Tygodniku Illustrowanym" 11 kwietnia 1863 roku, mowa jest o tym, że poeta stracił żonę i dwoje dzieci' ${ }^{6}$.

Poruszony doświadczeniami młodego wdowca Kniaźnin poświęcił mu swój cykl żałobny i parafrazując mit o Orfeuszu i Eurydyce, opisał wielką miłość małżonków, splatającą się ze śmiercią ${ }^{7}$. W wierszu dedykacyjnym poeta następująco wytłumaczył przyjacielowi to odwołanie do sytuacji Orfeusza:

Com słyszał o nim, a widział na tobie,

Te czucia w jednej złączyłem osobie.

Równy żal mężów, równe żon przymioty -

To czujesz, co on, a on to czuł, co ty ${ }^{8}$.

Warto tu nadmienić, że Zabłocki prawdopodobnie nigdy do końca nie przebolał straty żony — nie ożenił się ponownie, a w 1795 roku wyjechał do Rzymu i tam przyjął święcenia kapłańskie.

Ze względu na mit orficki, poezja odgrywa ważną rolę w całym cyklu. Przede wszystkim jest ona dla Kniaźnina środkiem do okazania współczucia, empatii i zrozumienia dla Zabłockiego oraz połączenia się z nim — poetą i zbolałym mężem — w cierpieniu. W obliczu śmierci ukochanej osoby liryka staje się najlepszym sposobem wyrażania uczuć i opisu przeżyć wewnętrznych bohatera, a także drogą do poszukiwania ukojenia. Lira (w późniejszych przekazach: lutnia), czyli symbol miłości małżeńskiej

\footnotetext{
${ }^{5}$ Wyjątki z listu P[ana] Grümberga do P[ana] Jana Richtera o Fr. Zabłockim, [w:] Wizerunki i roztrzasania naukowe, red. J. Zawadzki, t. 7, Wilno 1839, s. 50-51.

${ }^{6}$ Franciszek Zabtocki (z drzeworytem), „Tygodnik Ilustrowany” 1863, nr z 11 kwietnia, s. 137.

7 Atrakcyjność takiego wykorzystania mitu dostrzegł także XX-wieczny poeta Czesław Miłosz, co zaowocowało wzruszającym poematem Orfeusz i Eurydyka. Wspólnym bodźcem do przywołania tej mitologicznej historii była również chęć podkreślenia tragizmu przeżywanych traumatycznych doświadczeń osobistych (w przypadku Miłosza związanych ze śmiertelną chorobą żony). Wędrówka Orfeusza po Hadesie opisana w tym utworze jest tak naprawdę drogą poety do szpitala, w którym miał się spotkać z umierającą małżonką. Por. Brama do Hadesu - Mitosz o swym poemacie „Orfeusz i Eurydyka”, [online], dostęp: 23 stycznia 2014, dostępny: <http://www.mariuszstaw.info/plikownia/materialy/milosz_orfeusz.pdf>.

${ }^{8}$ F. D. Kniaźnin, Do Franc[iszka] Mik[ołaja] Zabtockiego, [w:] Poezje Franciszka Dionizego Kniaźnina rękq własna pisane, t. 1-2, Kraków 2006, Wydawnictwo Collegium Columbinum, seria „Biblioteka Tradycji”, nr 57.
} 
i przyjaźni ${ }^{9}$, to jedyne oręże, jakie pozostaje Orfeuszowi, w obliczu osobistej tragedii. Dzięki niej mityczny śpiewak może niejako okazać światu swój ból i ma moc, by wzruszać wszelkie istoty (w tym także nieczułych władców krainy umarłych) i otworzyć wrota do piekieł. Pojmowanie liryki w ten sposób zostało zainspirowane ważną dla puławskiego poety tradycją antyczną (przetwarzane w poezji mity o Amfionie, Arionie i Orfeuszu, utrwalone dzięki Horacemu, Wergiliuszowi i Owidiuszowi) oraz staropolską (Jan Kochanowski w Muzie i w Trenach, Stanisław Herakliusz Lubomirski w Orfeuszu). Warto w tym miejscu nadmienić, że takie ujęcie wyjątkowego znaczenia liryki i czarownej mocy liry jako atrybutu poety-śpiewaka koresponduje także z późniejszymi utworami nawiązującymi do mitu o Orfeuszu, a przy tym podkreślającymi szczególną rangę liryki jako dziedziny artystycznej związanej pierwotnie z muzyką. Mam tu na uwadze na przykład takie utwory, jak Orfeusz Claudia Monteverdiego czy Orfeusz i Eurydyka Christopha Willibalda Glucka, w których akcentowano niezwykłą, magiczną rolę śpiewu i muzyki, jako przejawów artyzmu posiadających nadzwyczajną moc ukojenia serc, wyrażania ludzkich namiętności i wzruszania odbiorców ${ }^{10}$.

Kniaźnin opisuje w swoim cyklu drogę, jaką przebywa większość ludzi, którzy stracili ukochaną osobę, uwzględniając przy tym targające nimi, zmieniające się z upływem czasu emocje i po mistrzowsku ukazując nieustanną metamorfozę ich uczuć ${ }^{11}$. Początkowo bohater cyklu szuka wsparcia u przyjaciół („Luba, drużyno, przyjaciele moi, / pocieszcie, jeśli możecie"; Żal I), jednak szybo zdaje sobie sprawę z tego, że nikt nie zdoła go pocieszyć, więc tak jak Kochanowski w Trenie I („Wszystkie płacze, wszystkie łzy Heraklitowe [...] wszytki a wszytki za raz w dom się mój noście”"12) i XVII („A ja zatym łzy niech leję, / Bom stracił wszystkę nadzieję”13) szuka ukojenia we łzach: „Płyńcie, łzy gorzkie! ale zbolałemu / Folgę smutniejszą dajecie" (Żal $I$ ) oraz w samotności. Motyw płaczu jako ukojenia powraca potem w Żalu $I X$, kiedy to bezsilny Orfeusz wyznaje, że tak jak znana z mitologii Niobe, chciałby zamienić się w zdroje łez ${ }^{14}$ :

O gdyby jeszcze podług mej niedoli

Bóg mi dozwolił użyć własnej woli,

Nie kamieniem ja, ani drzewem jakiem $[\ldots]$

Ale stałbym się łzami, tylko łzami!

Bym się gorzkimi zalewał zdrojami

Na zawsze, boś mię na zawsze rzuciła.

\footnotetext{
${ }_{9}^{9}$ Zob. Lira, [w:] W. Kopaliński, Stownik symboli, Warszawa 2012, s. 198.

${ }^{10}$ Zob. Sz. Paczkowski, Apoteoza muzyki: Ficino i „L'Orfeo" Claudia Monteverdiego, [w:] Mit Orfeusza, red. S. Żerańska-Kominek, Gdańsk 2003, s. 144.

${ }^{11}$ Zob. też. R. Fieguth, Poezja $w$ fazie krytycznej $i$ inne studia z literatury polskiej, Izabelin 2000 (rozdz. O kompozycji cyklu Franciszka Dionizego Kniaźnina "Żale Orfeusza nad Eurydyką"(1783)), s. 100.

${ }^{12}$ J. Kochanowski, Tren I, [w:] tenże, Treny, oprac J. Pelc, wyd. 16 popr., Wrocław 2009, BN I 1, s. 5.

${ }^{13}$ Tenże, Tren XVII, [w:] tamże, s. 40.

${ }^{14}$ Por. tamże, s. 106-107.
} 
oraz w Żalu X:

Mnie tylko gorzkim zalewać się zdrojem,

Łzy moją karmią, łzy moim napojem,

A komu radość jest k’woli,

Płakać mi niechaj pozwoli.

W ostatnim z cytowanych fragmentów widoczne jest odwołanie do Metamorfoz Owidiusza, który tak właśnie obrazowo ujął cierpienie Orfeusza, zaznaczając, iż po ponownej stracie Eurydyki „ból, zgryzota i łzy były jego pokarmem” ${ }^{15}$.

Podmiot liryczny nie potrafi przyjąć do wiadomości, że Eurydyki już nie ma na świecie (Żal II). Mężczyzna nie jest w stanie rozstać się z żoną, postanawia więc odciać i zostawić sobie na wieczną pamiątkę jej długi, złoty warkocz. Opis tego warkocza zamieścił poeta w Żalu III.

Utnę jej włosy, ten warkocz złoty,

Co się rozpuszczał w długie uploty,

A straż trzymając nad jej wdziękami,

Igrał z wiatrami.

Jak wiadomo, jasne, igrające $\mathrm{z}$ wiatrem włosy już w literaturze baroku były symbolem kobiecego piękna i powabu. Warkocz ukochanej Orfeusz zamierza złożyć razem z należącymi do niej przedmiotami w skrzynce z kości słoniowej, której widok sprawia mu ból i cierpienie, przywołuje łzy i przypomina o tym, co się wydarzyło. Dostrzec tu można analogię do Trenu VII Jana Kochanowskiego, w którym podmiot liryczny zwracał się do ubiorów pozostałych po Urszulce tymi przejmującymi słowami: „Po co me smutne oczy za sobą ciągniecie? / Żalu mi przydajecie"16.

Śmierć sprawia, że bohater poematu Kniaźnina zaczyna inaczej postrzegać świat. W obliczu utraty ukochanej osoby niektóre, z pozoru ważne dotychczas rzeczy, stają się bezwartościowe. Takie przesłanie niesie $\dot{Z} a l l V$, w którym — podobnie jak w $\dot{Z}_{a}$ lu $V$ - podmiot liryczny w zwrotach kierowanych bezpośrednio do małżonki zwraca także uwagę na ulotność ludzkiego szczęścia utożsamianego przez niego z odwzajemnioną miłością oraz na nieoczekiwane zmiany losu ludzkiego:

I wyrok Delfów był niewątpliwy,

Żem ja na ziemi jeden szczęśliwy.

Byłem, to prawda, bo ciebie miałem!

Kochany wzajem, bóstwo kochałem.

Cóż ja dziś jestem, ciebie straciwszy?

$\mathrm{Z}$ najnieszczęśliwszych najnieszczęśliwszy.

W tych rozważaniach wielokrotnie powraca jedna, przygnębiająca myśl — człowiek dopiero po stracie kogoś bliskiego docenia to, co miał:

\footnotetext{
${ }^{15}$ Owidiusz, Metamorfozy, t. 2, oprac. S. Stabryła, przekł. A. Kamieńska, Wrocław 2004, s. 293.

${ }^{16}$ J. Kochanowski, Tren VII, [w:] tenże, Treny, s. 15, w. 3-4.
} 
Bogowie srodzy równie jak wspaniali

Życiem mię jeszcze na to darowali,

Abym znał lepiej, jak wielem utracił,

A tę łaskę wiecznymi łzy płacił.

$(\dot{Z} a l V I)$

Owych pasterzów pasterki weselą,

Niewinne żarty rozrywkami dzielą,

Bo są szczęśliwi, bo mają

To, czego utraty nie znają.

$(\dot{Z} a l X)$

O, jakież bóstwo ja miałem!

Znam jeszcze lepiej, kiedy postradałem.

Szczęśliwszy byłem, niżelim rozumiał.

$(\dot{Z}$ al XI)

W omawianym cyklu Kniaźnin nie pomija też milczeniem momentu śmierci Katarzyny $^{17}$ i w Żalu VI, tak jak Lubomirski w utworze Orfeusz ${ }^{18}$, w niezwykle poruszający sposób, szczegółowo opisuje jej wygląd i fizyczne oznaki poprzedzające moment odejścia na tamten świat. Katarzyna/Eurydyka umierała w bólach i cierpieniu.

Kiedy ów zamróz po białym jej ciele

Szedł, wyciskając zimny znój na czele,

A wźrok, szukając próżnej już pomocy,

Mglał i okropnej poddawał się nocy.

Kiedy siniejąc, usta się ścinały,

Chciała coś wyrzec, słowa zapadały,

Ręką mnie tylko za rękę ścisnęla

I z głębi serca żałośnie westchnęla.

I wtem skonała. [...]

Reakcją na śmierć najbliższej osoby jest tutaj omdlenie — z rozpaczy i bezsilności. Orfeusz nie jest w stanie znieść targających nim emocji. Odzyskawszy przytomność, nie może się pogodzić ze stratą i żałuje, że nie umarł razem z ukochaną. Jego duch powrócił do ciała po chwilowej utracie przytomności, duch Eurydyki zaś odszedł na zawsze... W całym cyklu podmiot liryczny kilkakrotnie wyznaje, że pragnie umrzeć: „Czemuż, o nieba, razem nie skonałem?” życia..." (Źal XVIII).

${ }^{17}$ Por. R. Fieguth, dz. cyt., s. 104.

${ }^{18}$ Zob. S. H. Lubomirski, Orfeusz, [w:] tenże, Poezje zebrane, t. 1, wyd. A. Karpiński, Warszawa 1995, s. 12.

${ }^{19} \mathrm{~W}$ Metamorfozach Orfeusz również chce umrzeć razem z małżonką, nie widzi sensu swego przebywania na ziemi bez niej i nie chce opuszczać Podziemi sam: „[... jeśli Przeznaczenie nie zechce mej żonie wyświadczyć tej łaski, to naprawdę nie mam po co wracać; radujcie się śmiercią obojga!" (Owidiusz, $d z$. cyt., s. 292). Podobną przemowę bohater wygłasza przed Plutonem także w Orfeuszu 
Mamy tu do czynienia ze swoistym dualizmem w sposobie ukazywania śmierci: $\mathrm{z}$ jednej strony przynosi ona człowiekowi cierpienie, $\mathrm{z}$ drugiej zaś jest rozumiana jako powtórne połączenie się kochanków i zdarzenie, które może nieść ulgę i stanowić ucieczkę od problemów.

Ponadto w Żalu VIII, tak jak w napisanym przez Giovanniego Alberto Ristoriego libretcie do opery I Lamenti d'Orfeo Giovanniego Claudio Pusquiniego, Orfeusz pragnie uczynić ofiarę ze swego życia i mówi, że wolałby umrzeć zamiast Eurydyki („Niech bym ja oddał głowę złoczynną, / Lecz ona była niewinną”).

Podmiot liryczny nie może się wyzbyć myśli o ukochanej, co jakiś czas wspomina o jej urodzie i przymiotach. W Żalu XI stwierdza, że poprzez piękno swej twarzy i zalety serca żona osłodziła mu najlepsze lata życia. Z kolei cały Żal VII poświęcony jest rozważaniom na temat uwiecznienia Eurydyki na obrazie, by w ten sposób choć po części zapewnić jej nieśmiertelność, czy też przywrócić ją do świata żywych i na zawsze uwiecznić jej piękno („O, pędzlu, którego praca / Życie umarłym przywraca / [...] Wskrześ Eurydykę i ożyw jej wdzięki!”). Rzecz ciekawa — podobnym zabiegiem posłużył się Kniaźnin w wydanym później poemacie Rozmaryn. Tworzenie obrazu staje się okazją do rozmyślania o urodzie ukochanej i cechach jej charakteru. Zabiegom tym towarzyszy typowe w takich sytuacjach idealizowanie zmarkej osoby. Podmiot liryczny nie potrafi jednak zdecydować, jaką Eurydykę chciałby widzieć na portrecie — spoglądającą na niego z niewinnością, która go ujęła na początku ich znajomości, czy z litością i czułością. W końcu uświadamia sobie smutną prawdę — nic nie ożywi zmarłej, na płótnie nie da się utrwalić tego, jaką była osobą, jedynie w sercu jej męża mogą pozostać te wspomnienia.

Bohaterem targają gwałtowne uczucia, które powracają do niego z różnym nasileniem. Stany, w jakich się znajduje, można by zobrazować za pomocą sinusoidy: po upadku następuje chwila wytchnienia, kiedy to bohater oddaje się miłym wspomnieniom, po czym znów przypomina sobie o nieszczęściu, które go spotkało. Początkowo odczuwa przede wszystkim ból, zaszokowanie, otępienie, zagubienie (Żale: I, II, III i $I V)$, którym towarzyszą łzy. Stopniowo pogrąża się w rozpaczy, ogarniają go żałość i niepokój, nie ma nadziei na ukojenie:

Dziś sam niepokój mię budzi

I targa na wszystkie strony,

Umysł mój rzuca się trudzi

Nieukojony.

Żałość w tym sercu srożeje,

Bodzie go zewsząd, przeszywa;

$\mathrm{Na}$ miejsce zbiegłej nadziei

Rozpaczy wzywa.

$(\dot{Z} a l V$

S. H. Lubomirskiego: „A jeśli suplik nie przyjmiesz daremnych, / Dozwól, niech tu z nią dni zażywam ciemnych, / A mnie i piekło, bylem z nią żył wszędzie, / Za niebo będzie” (S. H. Lubomirski, $d z$. cyt., s. 17). 
Wraz z kolejnymi przemyśleniami w bohaterze rodzi się złość na Jowisza za jego niesprawiedliwy i krzywdzący wyrok. W Żalu VIII, adresowanym do najwyższego z bogów, podmiot liryczny skarży się na swój los, co w końcu doprowadza go do bluźnierstwa ${ }^{20}$ :

Jowiszu! Lub cię stan nasz nie tyka,

Lub gorzkie bawią łzy śmiertelnika.

Nędzą Ci moją wzrok nasyciłem.

Żalu! Co czynisz? Zbluźniłem.

W omawianym cyklu pojawiają się rozważania nad możliwością empatii bogów. Idąc śladami Jana z Czarnolasu, który w Trenie XIV zastanawia się nad tym, czy Bóg jest obojętny na ludzkie prośby („Gdzie by też tak kamienne ten Bóg serce nosił, / Żeby tam smutny człowiek już nic nie uprosił?”21), Kniaźnin porównuje Plutona, boga mitycznego Podziemia, do bezdusznego głazu.

Ale on, jak ten głaz wryty;

Żadna go prośba nie łamie.

Głaz ten, mówię, nieużyty,

O który wspieram to ramię.

$(\dot{Z} a l X X)$

We wspomnianym już libretcie Ristoriego do opery I Lamenti d'Orfeo żalący się Kaliope Orfeusz także bluźni, uznając bogów za niewdzięcznych i niechętnych do pomocy:

Nigdy we mnie nie była niewdzięczności wada,

Chlubić się z tego mogę. Zaś u bogów zdrada!

Fałsz, niewdzięczność. Ach, jak mnie na to serce boli,

Że sprzyjać mi nie chcieli w tak ciężkiej niedoli ${ }^{22}$.

Brak nadziei na pomoc bliskich i bogów sprawia, że będący na skraju szaleństwa Orfeusz rozpoczyna tułaczkę w celu odszukiwania zmarłej małżonki (w Żalu IX):

Jak ptak ów wierny, ptak osierocony,

Nieszczęsny smutny, leci w obce strony,

$[\ldots]$

I wiecznie jęczy. Tak i ja za tobą,

Za moim światłem, duszy mej ozdobą,

Błędny, strapiony, sam nie wiedząc kędy,

Troskliwy jednak postępuję wszędy ${ }^{23}$.

${ }^{20}$ Zob. też: R. Fieguth, $d z$. cyt., s. 104-105, 116.

${ }^{21}$ J. Kochanowski, Tren XIV, [w:] tenże, Treny, s. 29.

${ }^{22}$ Tekst podaję na podstawie polskiego tłumaczenia autorstwa Józefa Andrzeja Załuskiego; zob. tenże, Lamenta Orfeusza, [w:] Zebranie rytmów przez wierszopisów żyjacych lub naszego wieku zesztych pisanych, t. 3, Warszawa 1754, s. 341-342.

${ }^{23}$ Orfeusz został tu porównany do cierpiącego, samotnego ptaka. Takim zabiegiem posłużył się także S. H. Lubomirski, który los Orfeusza przyrównał do doli słowika. Zob. S. H. Lubomirski, dz. cyt., s. 13. 
Żal i ból doprowadzają do tego, że szalejący z rozpaczy człowiek, tak jak w Georgikach Wergiliusza ${ }^{24}$ i Orfeuszu Lubomirskiego ${ }^{25}$, płacze i błąka się pośród borów, „gubiąc myśl biedną". Nasuwa to również skojarzenie z bukoliką Biona Na śmierć Adonisa, w której zrozpaczona po śmierci ukochanego Afrodyta „w boleści, w nędzy bezmiernej / [...] błądzi wśród lasów gęstwiny zielonej”"26. Rozpoczynająca się już w Żalu IX wędrówka jest poniekąd momentem przełomowym, w którym bohater przechodzi z biernej postawy w czynną — poszukiwania Eurydyki są bowiem jednocześnie próbą odnalezienia sensu życia, utraconego szczęścia i natchnienia poetyckiego ${ }^{27}$. Podczas tej wędrówki Orfeusz coraz silniej zaczyna odczuwać swoją samotność i wyobcowanie, co sprawia, że jeszcze bardziej niż przedtem oddala się od ludzi („Ja tylko od nich uciekam, / Ja tylko jeden wyrzekam", Żal X) i chce się ukrywać w ciszy i w ciemnościach („Pójdę, gdzie głucha cichość towarzyszy”, Żal XII; „Ledwo tu blady gdzie promień dolata / Tu się nieszczęsny ukryję od świata”, Żal XVI; „Cienia szukając twojego, trącam się tylko w noc ciemną”, Żal XVII), jak w utworze Lubomirskiego, w którym czytamy, iż tracki śpiewak:

Między okropne udał się padoły

Chcąc, by go słońce nigdy nie widziało

I smutne oko jasności nie znało ${ }^{28}$.

Oglądany oczyma wdowca świat, w którym dominują radość, miłosne spełnienie i szczęście, sprawia mu ból, jako że jest przeciwieństwem jego wewnętrznych przeżyć, sprowadzających się do wiecznej boleści („Ja zaś i zawsze, i zawsze, i zawsze / Wzdycham a jęczę strapiony, / Niczym niepocieszony!”, Żal X; „Każde się cieszy stworzenie, / Ja tylko w żalach, w tęskności", Żal XII).

Cierpienie spowodowane stratą doprowadza do skrajnego wycieńczenia organizmu, nie tylko pod względem psychicznym, ale także fizycznym. Śmierć ma niszczycielski wpływ nie tylko na tego, do kogo przychodzi, ale także na tych, którzy pozostają przy życiu. Ciało Orfeusza przeszyte jest boleścią, mężczyzna stopniowo traci siły. Podobnie cierpienia mitycznego śpiewaka ukazywał Lubomirski — wykreowany przez niego Orfeusz po śmierci Eurydyki staje się „chudy, wyschły jako list zwiędniały”29. Ponadto, podobnie jak Kochanowski w Trenie XIX (,Żałość moja długo w noc oczu mi nie

\footnotetext{
${ }^{24}$ W księdze czwartej Georgik Wergiliusz zaznacza, że Orfeusz, kierując się do Tenaru „Wkroczył [...] w las czarny i ponury, który trwoga ściemnia”; tenże, Georgiki, przekł. A. L. Czerny, Warszawa 1956, s. 88 .

${ }^{25}$ Poeta, opisując cierpienia Orfeusza, stwierdza, iż wdowiec „trapił się biedząc, lasy go widziały, / We łzach i żalu jemu pomagały” (zob. S. H. Lubomirski, $d z$. cyt., s. 12) oraz że „Szedł w dzikie lasy i puste jaskinie, / Gdzie ptak nie żyje ani źrzódło płynie" (tamże, s. 13).

${ }^{26}$ Bion, Na śmierć Adonisa, [w:] Sielanka grecka, oprac. J. Łanowski, Wrocław 2007, s. 121.

${ }^{27}$ Zob. R. Fieguth, dz. cyt., s. 107.

${ }^{28}$ S. H. Lubomirski, dz. cyt., s. 12-13.

${ }^{29}$ Tamże, s. 13.
} 
dała / Zamknąć i zemdlonego upokoić ciała”30), Orfeusz zmaga się z bezsennością („Żal, co mi gorzką boleścią oddycha, / Sen z oczu łzami wypycha”, Żal X), a we śnie upatruje ukojenia:

Sen tylko jeden dla strapionych mily.

Mimo łez tylu i tyś mię porzucił!

Ratuj na chwilę, byś przynajmniej siły,

Dla żalu wrócił.

(Źal XXII)

Śmierć ukochanej osoby sprawia, że bohater, który jest przecież poetą i śpiewakiem, staje się także obojętny na piękno otaczającego świata. W zwrotach do gwiazd, słońca, księżyca i ptaków podkreśla, że ich piękno jest daremne i zbędne w obliczu śmierci Eurydyki. Kniaźnin odwołuje się w ten sposób do utworów żałobnych poświęconych Zabłockiemu, zamieszczonych w Erotykach ${ }^{31}$. Ta obojętność podmiotu lirycznego wobec zjawisk natury jest kolejnym wyrazem poczucia braku sensu życia wynikającego z utraty małżonki.

Orfeusz nie tylko z niczego się nie cieszy, ale także niczego się nie lęka. Straszne do niedawna odgłosy puszczyka i sowy ${ }^{32}$, według wierzeń ludowych wieszczące nieszczęście, obecnie nic nie znaczą dla podmiotu lirycznego:

Ptaki nieszczęsne! Czymże mi grozicie?

Nieszczęściem moim jest życie.

(Zal XII)

Nie napawa go również strachem droga do Hadesu, opisana w Żalu XIX $X^{33}$. Co ciekawe, ta obojętność staje się poniekąd siłą i atutem Orfeusza, który w swej zrazu pozornej bezsilności, wyzbywa się z czasem strachu i kierowany tęsknotą oraz bezgraniczną miłością ${ }^{34}$, decyduje się pójść do samych piekieł, by odzyskać żonę. W omawianym cyklu zejście do krainy umarłych nabiera całkiem nowego znaczenia — opis tej wędrówki jest zapewne próbą ukazania stanu psychicznego, w jakim znajdował się Zabłocki po starcie żony, przede wszystkim jego zobojętnienia, odrętwienia, niechęci do życia oraz nieustannego pragnienia śmierci.

Odruchem typowym w sytuacji śmierci ukochanej osoby jest rozmyślanie o tym, co się z nią stało po zgonie, oraz wyobrażanie sobie zaświatów w ziemski sposób. Hades ukazany jest w Żalach jako mroczne, przygnebiające miejsce, w którym błąkają się

${ }^{30}$ J. Kochanowski, Tren XIX albo sen, [w:] tenże, Treny, s. 43.

${ }^{31}$ Por. wiersze poświęcone F. Zabłockiemu, [w:] F. D. Kniaźnin, Erotyki, t. 2, Warszawa 1779 (dalej skrót: E): Do gwiazd (E, t. 2, VIII 34, s. 206-207), Do stońca (E, t. 2, VIII 36, s. 210-211), Do Echa (E, t. 2, VIII 35, s. 207-210).

${ }^{32}$ Zob. Sowa, [w:] W. Kopaliński, dz. cyt., s. 399, 400.

${ }^{33}$ Zob. też. R. Fieguth, dz. cyt., s. 111-112.

${ }^{34}$ Informację o tym, że Orfeusz, schodząc do piekieł, nie odczuwał strachu, odnajdujemy także u S. H. Lubomirskiego, który podkreśla, iż zrozpaczony wdowiec „poszedł bez strachu w okropne ciemności, / Miłość mu tylko dodała śmiałości” (S. H. Lubomirski, dz. cyt., s. 13). 
osamotnione, zagubione, wyobcowane dusze zmarłych. Orfeusz jest przekonany, że Eurydyka cierpi w zaświatach. Oczyma wyobrá́ni widzi umęczoną, potrącaną przez przechodniów duszę, stojącą nad brzegiem Styksu, która niestrudzenie, choć z gasnącą nadzieją, wypatruje swego męża. Bezradna, załamana kobieta omiata wzrokiem tysiące idących na skazanie zmarłych, a nie widząc między nimi Orfeusza, zaczyna powoli wątpić w szczerość jego uczuć35.

Rozpamiętywanie utraconej miłości jest kolejnym nieodłącznym elementem żałoby, a także (co ciekawe) popularnym motywem pasterskim. Orfeusz nieustannie zestawia dobrą, szczęśliwą przeszłość z naznaczoną cierpieniem teraźniejszością. O ukochanej przypominają mu także miejsca, w których spędzali wspólnie chwile. Jednym z nich jest łąka z jaworem, pod którego cieniem Eurydyka lubiła wypoczywac ${ }^{36}$. Drzewo to, tak jak w sielance Laura i Filon Franciszka Karpińskiego, jest tu miejscem schadzek kochanków. Orfeusz oddaje się bolesnym wspomnieniom, przed oczyma stają mu obrazy minionego szczęścia: pierwsze spotkanie, gra na lirze dla ukochanej, pierwszy pocałunek, rumieńce na jej policzkach i nałożenie wieńca na jego skronie.

Poprzez wykorzystanie motywów sielankowych przy kreśleniu wspomnień podmiotu lirycznego Kniaźnin akcentuje wzniosłe i idealne uczucie, które połączyło małżonków i zostało zaburzone przez śmierć. Opisane w Żalu XI i XIV wspomnienia miłosnych uniesień przypominają sceny sielankowe, w których zakochani cieszą się swoją obecnością i odwzajemnionym uczuciem w wiejskim zaciszu, na łonie idealnej natury. Eurydyka, niczym bohaterka wspomnianej sielanki Karpińskiego, uplata wianek dla Orfeusza, czyni też mu wyznanie miłosne: „Orfeju, masz mnie wzajemną, / Kiedym ja z tobą, bądź szczęśliwy ze mną", które jest parafrazą słów z jednej z pasterek Kniaźnina opublikowanych w Erotykach w 1779 roku (inc. „Tyrymach — pasterz, śpiewak doskonały”): „[...] zdarz łaskę wzajemną: / ja z tobą będę, ty fortunna ze mną". Ukochana jest w oczach mężczyzny bóstwem oraz uosobieniem piękna, co było typowym zabiegiem stosowanym w oświeceniowych sielankach czułych ${ }^{37}$. Jak zauważa Rolf Fieguth, takie uduchowienie Eurydyki jest także sygnałem „neoplatońskiej tradycji dyskursu miłosnego" ${ }^{38}$. Ponadto w wierszu dedykacyjnym Kniaźnin nazywa żonę przyjaciela imieniem Chloe, co może stanowić nawiązanie do antycznej powieści pasterskiej autorstwa Longosa Dafnis i Chloe. Kolejnym utartym elementem bukolicznym jest wykorzystany w Żalu XIV motyw rycia na korze drzew - Orfeusz w miłosnym uniesieniu zapisuje tam następujące słowa: „Tu człek niebieską duszę posiadał”. Jak zauważa Teresa Kostkiewiczowa: „w wersji znajdującej się w Poezjach

\footnotetext{
${ }^{35}$ Motyw zwątpienia Eurydyki w miłość małżonka pojawia się także w operze Orfeusz i Eurydyka Ch. W. Glucka, jednak dopiero podczas drogi z Podziemia do świata żywych. Bohaterka nie rozumie, dlaczego ukochany nie patrzy na nią w czasie tej wędrówki i dochodzi do wniosku, że już jej nie kocha. Por. J. Kański, Przewodnik operowy, Kraków 1995, s. 141. Zob. też: R. Fieguth, dz. cyt., s. 114.

${ }^{36}$ Zob. R. Fieguth, dz. cyt., s. 109-110.

${ }^{37}$ A. Dobak, Sielanka, [w:] Stownik literatury polskiego oświecenia, red. T. Kostkiewiczowa, WrocławWarszawa-Kraków 2006, s. 577.

${ }^{38}$ R. Fieguth, dz. cyt., s. 103.
} 
Orfeusz zachowuje się jak czuły pasterz, opłakujący śmierć ukochanej" ${ }^{39}$. Widoczne jest tu odwołanie do innych utworów poświęconych trackiemu poecie, na przykład do wspomnianego już Orfeusza Monteverdiego, ponieważ tam tytułowy bohater również jest pasterzem ${ }^{40}$.

Po śmierci Eurydyki świat nagle ulega gwałtownej przemianie i jawi się jako antyarkadia - przestrzeń posępna, ponura i przygnębiająca. To spowita mgła, nieprzyjazna kraina, w której dominują ciemne barwy, a wszędzie czai się zło i zagrożenie (na przykład Żal XII, XV,XVI). Zgodnie z założeniami sentymentalizmu przyroda staje się tu odbiciem uczuć bohatera ${ }^{41}$.

Gaje Izmaru! byłyście mi lube,

Wesołe przy was chwile odbywałem.

Drzewa te, skacząc, czyniły mi chlubę,

$[\ldots]$

Kiedy zagrałem.

Dziś tu posępno, a gdy tęskne tony,

$\mathrm{Z}$ jęczącej lutni żałość dobyć pragnie,

Ledwo się który wierzchołek zielony

$\mathrm{Z}$ niechcenia nagnie.

$(\dot{Z} a l X V)$

Kniaźnin nawiązuje w ten sposób także do poprzednich realizacji mitu, bowiem już w Georgikach Wergiliusza przyroda jest poruszona cierpieniem wdowca i wraz z nim pogrąża się w żalu, a motyw ten odnajdujemy także w późniejszych realizacjach tematu, mianowicie w Orfeuszu Monteverdiego ${ }^{42}$ oraz poemacie Orfeusz i Eurydyka Roberta Henrysona ${ }^{43}$.

W Żalach Orfeusza nad Eurydyką istotne jest także to, w jaki sposób na śmierć tytułowej bohaterki reaguje otoczenie. Ci, którzy spotykają na swej drodze legendarnego śpiewaka, dostrzegając, jak bardzo kochał swoją żonę, niejako wyczuwają ogrom jego cierpienia, bez wyjątku są poruszeni tą sytuacją i współczują mu. Bliscy nie potrafią pomóc Orfeuszowi, ponieważ sami również cierpią. W wierszu dedykacyjnym podmiot liryczny określa siebie jako "uczestnika żalu” i świadka rozpaczy, zaś w Żalu I załamany wdowiec zwraca się do najbliższego przyjaciela w następujących słowach:

Filonie, słodka twej przyjaźni rada

Pierwszy raz u mnie daremną.

Abym nie płakał próżno mi przekłada

Ten, który płacze sam ze mną.

\footnotetext{
${ }^{39}$ T. Kostkiewiczowa, Kniaźnin jako poeta liryczny, Wrocław-Warszawa-Kraków-Gdańsk 1971, s. 63.

${ }^{40}$ Por. Sz. Paczkowski, dz. cyt., s. 142.

${ }^{41}$ T. Kostkiewiczowa, Sentymentalizm, [w:] Stownik literatury polskiego oświecenia, s. 570.

${ }^{42}$ Por. J. Kański, dz. cyt., s. 246.

${ }^{43}$ Zob. S. Żerańska-Kominek, Portret wenusjańskiego artysty w balladzie Roberta Henrysona „Orpheus and Euridice", [w:] Mit Orfeusza, s. 63.
} 
W przedostatnim z cytowanych wersów pojawia się kolejne odwołanie do twórczości Mistrza z Czarnolasu, któremu również doradzano nie płakać: „»Próżno płakaću — podobno drudzy rzeczecie" ${ }^{34}$.

Nad Orfeuszem litują się także zupełnie obce osoby, które są zadziwione jego miłością do żony, nieosłabioną nawet przez śmierć. Kniaźnin nawiązuje do wersów poświęconych Urszulce w Trenie XII Jana z Czarnolasu („Żaden ociec podobno barziej nie miłował / Dziecięcia, żaden barziej nad mię nie żałowal"45) i w Żalu $X$ modyfikuje je tak, by ukazywały wyjątkowość i jednostkowość uczucia Orfeusza do małżonki i wymiaru cierpienia bohatera:

Tu starzec jakiś rzecze zadziwiony:

„Żaden tak jeszcze nie żałował żony,

Żaden tak jeszcze nie ślochał,

Bo też tak żaden nie kochał".

W swoim śnie, poprzedzającym zejście do Hadesu, oraz w czasie rzeczywistej wyprawy Orfeusz wzrusza swym losem także pozornie nieczułych, oziębłych mieszkańców Podziemia: przewoźnika Charona, sędziów, Erynie oraz samego Plutona.

Kniaźnin w omawianym cyklu żałobnym, tak jak Kochanowski w Trenach, wykorzystał elementy epicedium. Bez wątpienia pojawia się tam exordium (wiersz dedykacyjny Do Franciszka Mikołaja Zabtockiego, Żal II, Żal VI), laudatio i iacture demonstratio (Żal I, IV, V,VI, VII), luctus (Żal VII, XII, XI) i comploratio (Źal IX, X). Nie ma natomiast napomnienia (exhortatio) — puławski poeta nie potrafi dać mądrych rad (oprócz ogólnikowego przesłania, że należy pogodzić się z boskimi wyrokami), ponieważ sam jest empatycznym uczestnikiem żalu i cierpi razem z wdowcem. Orfeusz nie otrzymuje także ostatecznie pocieszenia (consolatio). Co prawda, opisany w Żalu II sen jest niejako konsolacją dla umęczonego wdowca, jednak momenty przebudzenia, tak jak finalna scena, są pasmem niekończącego się cierpienia. Miłość była sensem życia bohatera cyklu. Po tym, jak wędrówka do Hadesu okazała się daremna, Orfeusz został sam na świecie z myślą, że przez swój błąd stracił ukochaną na zawsze, zatem pocieszenie nie nadejdzie ${ }^{46}$. Wyrzucony poza bramy piekieł bohater, pozostaje w żałobie, w swej dotkliwej samotności i boleści.

Co bardzo intersujące, Kniaźnin modyfikuje zakończenie opowieści o wędrówce mitycznego śpiewaka. W oświeceniowym cyklu Orfeusz, niosący na plecach cień małżonki ${ }^{47}$, potyka się o próg i upada, a odwraca się z wynikającej z miłości troski i ze strachu o ukochaną, która przewraca się razem z nim. Poeta odchodzi tym samym od podań mitologicznych, wedle których Orfeusz odwrócił się, wbrew zakazowi władców

\footnotetext{
${ }^{44}$ J. Kochanowski, Tren I, [w:] tenże, Treny, s. 7.

${ }^{45}$ Tenże, Tren XII, [w:] tenże, Treny, s. 24.

${ }^{46}$ Por. R. Fieguth, $d z$. cyt., s. 119-120.

${ }^{47}$ Kniaźnin podąża za tradycją i — tak jak Wergiliusz i Owidiusz — ukazuje odwiedzane przez Orfeusza Podziemie jako krainę cieni.
} 
Podziemia, ze zwykłej ciekawości, i nawiązuje do późniejszych utworów o Orfeuszu, w których tracki śpiewak, kierowany miłością, spogląda za siebie, ponieważ niepokoi się o ukochaną. W taki sposób zostało to ukazane np. w operze Monteverdiego (Orfeusz martwi się o żonę i spogląda na nią z troski - chce sprawdzić, czy ukochanej nie porwały złowrogie Erynie ${ }^{48}$ ) i Glucka (Orfeusz odwraca się, by okazać czułość ukochanej, która wątpi w jego uczucia i z rozpaczy traci siły i chwieje się $\left.e^{49}\right)$.

W Żalach Orfeusza nad Eurydyką warto zwrócić także uwagę na metafory, jakich poeta używa do opisu omawianego tu zjawiska. W wierszu dedykacyjnym śmierć określana jest jako „zgon srogi”, natomiast w Żalu II nazywana jest gońcem wyroku twardego, którego nie wzrusza żadna łza, oraz śmiertelnym gońcem, budzącym ze snu, którym było życie. Porównana jest także do snu, przez co budzi skojarzenie z mitycznymi podaniami, według których Tanatos i Hypnos byli braćmi. Zgon zostaje także porównany do gaśnięcia zorzy oraz do losu zerwanego kwiatu, przez co poeta eksponuje ulotność i kruchość ludzkiego życia:

Tak błyska razem i gaśnie

Zorza na niebie różana;

Róża nadobna tak właśnie

Ledwo rozkwitnie, zerwana.

(Żal II)

Śmierć ukazana jest także jako odejście zmarłej od ukochanego. Porzucony mężczyzna zadaje małżonce przepełnione żałością i rozpaczą pytanie: „O, ty jedyna, Eurydyko miła, / $\mathrm{Na}$ cóżeś ty mnie teraz zostawiła?”. Podobne słowa kieruje do niej w Żalu IX: „Niestety, tyś mię na zawsze rzuciła, / Moja pociecho, Eurydyko miła!” Śmierć ukochanej osoby jest postrzegana także jako utrata duszy wdowca — „Goniec wyroku twardego, / [...] Uchwycił duszę mej duszy” (Żal II), „Tu człek niebieską duszę posiadał / [...] lecz ją postradał" ( Żal XIV). W Żalu VIII śmierć pojmowana jest natomiast jako kara zesłana przez bogów (,Z jakichże przyczyn mojej niebodze / Być ukaraną przyszło tak srodze?”), podobnie w Żalu XXIII jako „wyrok boskiego prawa”, a w Żalu XI jako zniknięcie ze świata. W Żalu VIII Kniaźnin po raz kolejny odwołuje się do mitologii, pisząc o przecięciu pasma życia przez Parki.

W omawianym cyklu tak naprawdę to nie sama w sobie śmierć jako odwiecznie zagrażające zjawisko jest przyczyną cierpienia i rozpaczy. Dopiero połączona z miłością sprawia ból niemożliwy do ukojenia, pozostawia pustkę, której nie da się zapełnić, a niejednokrotnie wyniszcza tych, którzy zostają na ziemi, i odbiera im sens życia. Śmierć dla kogoś, kto kocha, zawsze będzie tragedią, której nie da się nigdy do końca wypowiedzieć i opisać. Tragedią postrzeganą przez każdą osobę cierpiącą jednostkowo i indywidualnie. Z drugiej strony jednak, wykorzystane w Żalach Orfeusza nad Eurydyka Kniaźnina rozliczne odwołania do mitologii i literatury funeralnej miały

\footnotetext{
${ }^{48}$ Zob. J. Kański, dz. cyt., s. 245-246.

${ }^{49}$ Tamże, s. 141.
} 
uświadomić, że śmierć jest także zjawiskiem uniwersalnym, powtarzalnym i przez wieki odbieranym tak samo - jako dramatyczne wydarzenie, po którym bliscy zmarłego często nie potrafią sobie poradzić z żalem, tęsknotą i bólem.

Uruchomiona przez autora Żalów tradycja kulturowa (zwłaszcza zaś wpisana weń śródziemnomorska tradycja mitologiczna), miała stanowić w jego artystycznym zamyśle rodzaj pocieszenia (consolatio) dla przyjaciela, a jednocześnie najbliższego odbiorcy cyklu — poety Franciszka Zabłockiego / Orfeusza — cierpiącego po stracie swej ukochanej żony. Miała być nie tylko oznaką empatii, lecz również kulturowym znakiem, że w swym traumatycznym doświadczeniu Zabłocki nie jest odosobniony, a przy tym — serdecznym wyrazem nobilitacji jego sytuacji egzystencjalnej.

Beata Prokopczyk

"I LIVED ONLY IN ONE, FAVOURITE. SHE DIED! I LOST EVERYTHING" — on love and death in Orpheus's Griefs over EuRIdice Written by Franciszek Dionizy Kniaźnin

\section{Summary}

The subject deliberated upon in the present paper is the motive of death as presented in Żale Orfeusza nad Eurydyka funeral series by Franciszek Dionizy Kniaźnin. The collection in question originated in a tragic event in the life of Franciszek Zabłocki, Kniaźnin’s friend, whose beloved wife Katarzyna passed away shortly after the couple had married. Deeply moved by the young widower's experiences, Kniaźnin dedicated the aforementioned series to Zabłocki, as he described, against the background of the Orpheus and Eurydice myth, the intermingling of the couple's great love and death. The chief focus of the paper is on the strategies of approaching the theme of death, on how it is presented and perceived, as well as on the emotions it evokes. In Żale Orfeusza..., death, on the one hand, is shown from the perspective of a devastated individual, and on the other, through references to the popular myth and Jan Kochanowski's Lamentations (Treny), placed within a wider cultural and literary context which indicates universality. 